\title{
Article
}

\section{Herbal Infusions as a Valuable Functional Food}

\author{
Elżbieta Studzińska-Sroka 1,*iD, Agnieszka Galanty ${ }^{2}{ }^{\mathbb{D}}$, Anna Gościniak $^{1}$ (D), Mateusz Wieczorek ${ }^{1}$, \\ Magdalena Kłaput ${ }^{3}$, Marlena Dudek-Makuch ${ }^{1}$ and Judyta Cielecka-Piontek ${ }^{1} \mathbb{D}$
}

1 Department of Pharmacognosy, Poznan University of Medical Sciences, Swiecickiego 4, 60-781 Poznań, Poland; annagos97@gmail.com (A.G.); mateuszwieczorek23@gmail.com (M.W.); dudum@poczta.onet.pl (M.D.-M.); jpiontek@ump.edu.pl (J.C.-P.)

2 Department of Pharmacognosy, Faculty of Pharmacy, Jagiellonian University Medical College, Medyczna 9, 30-688 Kraków, Poland; agnieszka.galanty@uj.edu.pl

3 Department of Pediatric Gastroenterology and Metabolic Diseases, Poznan University of Medical Sciences, 27/33 Szpitalna Str., 60-572 Poznań, Poland; magdalena.klaput@ump.edu.pl

* Correspondence: elastudzinska@ump.edu.pl

check for updates

Citation: Studzińska-Sroka, E.; Galanty, A.; Gościniak, A.; Wieczorek, M.; Kłaput, M.; Dudek-Makuch, M.; Cielecka-Piontek, J. Herbal Infusions as a Valuable Functional Food. Nutrients 2021, 13, 4051. https:// doi.org/10.3390/nu13114051

Academic Editors: Laura Domínguez Díaz, Montaña Cámara and Virginia Fernández-Ruiz

Received: 7 October 2021

Accepted: 10 November 2021

Published: 12 November 2021

Publisher's Note: MDPI stays neutral with regard to jurisdictional claims in published maps and institutional affiliations.

Copyright: (c) 2021 by the authors. Licensee MDPI, Basel, Switzerland. This article is an open access article distributed under the terms and conditions of the Creative Commons Attribution (CC BY) license (https:/ / creativecommons.org/licenses/by/ $4.0 /)$.

\begin{abstract}
Herbal infusions are an underestimated and easy to intake a source of biologically active natural compounds (polyphenols), which, in the dissolved form, are more easily absorbed. Therefore, this study aimed to assess the potential of herbal infusions as a functional food to reduce postprandial hyperglycemia (inhibition of $\alpha$-amylase and $\alpha$-glucosidase) and to reduce the effects of increased blood glucose level (antioxidant effect-DPPH, CUPRAC, and $\mathrm{Fe}^{2+}$ chelating assays, as well as antiinflammatory activity-inhibition of collagenase). We showed that polyphenols are present in the examined aqueous herbal infusions (including chlorogenic and gallic acids). Subsequently, our research has shown that herbal infusions containing cinnamon bark, mulberry leaves, and blackberry fruits most strongly inhibit glucose release from complex carbohydrates, and that all herbal infusions can, to different degrees, reduce the effects of elevated blood sugar. In conclusion, infusions prepared from herbal blends could be recommended to prevent type II diabetes.
\end{abstract}

Keywords: antidiabetic activity; polyphenols; antioxidant activity; inhibition of $\alpha$-glucosidase; inhibition of $\alpha$-amylase; inhibition of collagenase

\section{Introduction}

Diabetes is a metabolic disease characterized by a chronic condition of hyperglycemia. According to the World Health Organization (WHO), it already affects 422 million adults worldwide [1]. As a result of diabetes development, the process of glycation of proteins, lipids, and nucleotides increases due to the persistence of high blood glucose levels. The reactive dicarbonyl molecules formed as a result of this glycation react with the amino groups of proteins, leading to the synthesis of advanced irreversible glycation products (AGEs). AGEs, by connecting to a specific receptor for advanced glycation end-products receptor found on the surface of e.g., lymphocytes, cardiomyocytes, or neurons of the central and peripheral nervous system, activate appropriate transcription factors, and induce the synthesis of reactive oxygen species. This intensifies the oxidation of glucose (glycoxidation) and lipids (lipoxidation), leading to the development and management of diabetes complications such as retinopathy, nephropathy, and diabetic neuropathy [2].

The development of diabetic complications also results from the insufficient effectiveness of pharmacotherapy of synthetic drugs [3]. Given the aging population, the trend of developing diabetes and the limited efficacy of synthetic drug therapy will be increasing. The strategy of combating type II diabetes involves also the change in the pharmacotherapy, from the use of old drug groups (e.g., sulfonylurea derivatives) that act directly in pancreatic cell membranes, and often produce side effects [4,5], to new therapeutic groups (e.g., dipeptidyl peptidase- 4 inhibitors), based on the mechanisms of action in the intestine [6]. The compounds inhibiting $\alpha$-glucosidase and $\alpha$-amylase also have their mechanism in 
the intestine. Glucosidases are responsible for the reduction of dietary carbohydrates into simple sugars that are quickly absorbed by the small intestine [7]. The $\alpha$-glucosidase and $\alpha$-amylase inhibitors can reduce hyperglycemia, and decreased the side effects of hyperglycemic drugs.

Diet is an important factor in proper carbohydrate metabolism. Dietary ingredients not only affect the reduction of postprandial glucose, but also may even regulate blood sugar [8]. The most important mechanisms of natural compounds for lowering sugar into the blood include: inhibiting their absorption, increasing their metabolism by stimulating insulin secretion and degradation in peripheral cells, and accelerating sugar excretion by inducing increased renal diuresis $[9,10]$. Raw plant materials are often used to support type II diabetes as herbal drugs. According to the guidelines of the Committee on Herbal Medicinal Products, raw plant materials can be registered as herbal drugs as a result of their wellestablished use and traditional use procedure [11]. Therefore, the preventive or curative effects of herbal raw materials can be a significant support in combating diabetes, together with a proper diet or using appropriate functional food. The compounds most responsible for the antidiabetic activity of plant materials include: flavonoids, anthocyanins, phenolic acids, some polysaccharides such as inulin which are not degradable to monosaccharides, alkaloids (deoxynojirimycin, found in mulberry leaves), as well as tannins or ingredients of essential oils, including cinnamaldehyde, found in a large amount in the cinnamon bark [12].

Herbal infusions are an easy-to-apply form of the herbs, which is an important argument, especially for senior patients with swallowing problems. Plant infusions also provide a very good distribution of active compounds in the intestine, which results in their effectiveness. The significant availability of a variety of herbal blends (HBs) for infusions preparations in the markets of each country is also important. In the view of the "silent epidemic" of diabetes II, hypoglycemic infusions can be an important element in combating the development of this disease.

In this way, our study aimed to investigate the antidiabetic potential of HBs infusions dedicated as supportive treatment of diabetes.

\section{Materials and Methods}

\subsection{Herbal Tea Blends}

Seven HBs, often recommended to patients or people at risk of developing diabetes II, were included in the study. The tested HBs were all produced by Polish herb packaging companies, and were purchased in pharmacies and herbal stores in Poznan, Poland. The detailed compositions of the blends are presented in Table 1.

Table 1. Composition of the herbal tea blends.

\begin{tabular}{cc}
\hline Herbal Blend & Herbals Content of the Preparations \\
\hline HB1 & Mori albi folium $100 \%$ \\
HB2 & Mori albi folium $25 \%$, Phaseoli pericarpium $25 \%$, Fagopyrum esculentum squama $25 \%$, Taraxaci radix $12.5 \%$, Urticae \\
fB3 & Phaseolium $12.5 \%$ \\
HB4 & Phaseoli pericarpium $40 \%$, Urticae herba vel Urticae folium $30 \%$, Graminis rhizoma $20 \%$, Taraxaci herba et radix $10 \%$ \\
HB5 & Mori albi folium $70 \%$, Cinnamomi cortex $30 \%$ \\
HB6 & Mori albi folium $95 \%$, Cinnamomi cortex $5 \%$ \\
HB7 & Ribes nigrum fructus $29 \%$, Aronia fructus $29 \%$, Mali fructus $26 \%$, Mori albi folium $15,4 \%$, Fagopyrum esculentum \\
& squama $0.3 \%$, Phaseoli pericarpium $0.3 \%$
\end{tabular}




\subsection{Chemical Reagents}

Ethanol, Folin-Ciocalteu reagent, (Merck, Darmstadt, Germany), 3,5-dinitrosalicylic acid, 2,2-diphenyl-1-picrylhydrazyl (DPPH), 4-nitrophenyl $\alpha$-D-glucopyranoside (PNPG), $\alpha$-glucosidase, $\alpha$-amylase, acetonitrile, collagenase from Clostridium histolyticum, formic acid, iron (II) chloride tetrahydrate, ferrozine, N-[3-(2-Furyl)acryloyl]-Leu-Gly-Pro-Ala (FALGPA), neocuproine, tricine, (Sigma-Aldrich, St. Louis, MO USA); aluminum chloride anhydrous, ammonium acetate, calcium chloride, copper (II) chloride dihydrate, disodium hydrogen phosphate dodecahydrate, methanol, sodium carbonate anhydrous, sodium dihydrogen phosphate dehydrate, sodium chloride, sodium hydroxide, and sodium phosphate monobasic (Avantor Performance Materials Poland S.A., Gliwice, Poland), were used. Standards: gallic acid and acarbose, ethylenediaminetetraacetic acid (EDTA) (SigmaAldrich, St. Louis, MO USA), chlorogenic acid, protocatechuic acid, quercetin, and rutin (Carl Roth GmbH + Co. KG, Karlsruhe, Germany) were used.

\subsection{Extracts Preparations}

The infusions were prepared by pouring a 2-g fix sachet with $200 \mathrm{~mL}$ of boiling distilled water. For different weight sachets, the amount of water was proportional. Herbs were infused under a cover for $15 \mathrm{~min}$. The resulting infusion was concentrated using a vacuum evaporator to a volume of $25 \mathrm{~mL}$ or $10 \mathrm{~mL}$ to obtain the initial test concentrations (weight of $\mathrm{HB} / \mathrm{mL}$ ).

\subsection{Total Phenolic Content (TPC) and Total Flavonoid Content (TFC) Analysis}

The TPC was determined by the modified Folin-Ciocalteu method [13]. Briefly, $25.0 \mu \mathrm{L}$ of each extract or gallic acid solution at different concentrations were mixed with $200.0 \mu \mathrm{L}$ distilled water and $15.0 \mu \mathrm{L}$ of Folin-Ciocalteu reagent, and allowed to react at room temperature for $3 \mathrm{~min}$. Finally, $60.0 \mu \mathrm{L}$ of aqueous solution of sodium carbonate $(20.0 \%$, $w / v)$ was added, and the mixture was incubated in 96 well plates at room temperature for $30 \mathrm{~min}$. The absorbance was read at $760 \mathrm{~nm}$ (Multiskan GO 1510, Thermo Fisher Scientific, Vantaa, Finland). The blank sample contained water instead of the extract or gallic acid solution. The total phenolic concentration was calculated from a calibration curve $y=0.0922 x-0.0199\left(R^{2}=0.9999\right)$, using gallic acid as a standard $(0.52-8.33 \mu \mathrm{g} / \mathrm{mL})$, and the obtained results were expressed as the gallic acid equivalents (GAE) (mg gallic acid per $\mathrm{g}$ of $\mathrm{HB}$ or plant material). The polyphenol content of the daily dose recommended by the manufacturer was also calculated.

The TFC was determined according to the aluminum chloride colorimetric method, in which $100.0 \mu \mathrm{L}$ of the extract or quercetin solution at different concentrations were mixed with $100.0 \mu \mathrm{L} 2 \%$ methanolic solution of aluminum chloride (complexing reagent), and incubated in 96 well plates at room temperature for $10 \mathrm{~min}$. The absorbance was read at $415 \mathrm{~nm}$ (Multiskan GO 1510, Thermo Fisher Scientific, Vantaa, Finland). The blank contained methanol instead of aluminum chloride solution. The TFC was calculated from a calibration curve $y=0.0262 x-0.0206\left(R^{2}=0.9998\right)$, using quercetin as a standard $\left(1.625-50.0 \times 10^{-3} \mathrm{mg} / \mathrm{mL}\right)$. The results were expressed as the quercetin equivalents (mg QE/g HB or plant material).

\subsection{High-Performance Liquid Chromatography (HPLC) Analysis}

Flavonoids and phenolic acids content was determined as described previously [14], using a Dionex HPLC system, with a PDA 100 detector, and a Hypersil Gold (C-18) column $(5 \mu \mathrm{m}, 250 \times 4.6 \mathrm{~mm}$, Thermo EC). The mobile phase consisted of $1 \%$ formic acid in water (A) and acetonitrile (B), in a gradient mode $5-60 \%$ B over $60 \mathrm{~min}$. The compounds were identified by comparing their retention times and UV spectrum with the standards. Quantitative analysis was based on measuring the peak area regarding the appropriate standard curve prepared from five concentrations $(0.0625-1 \mathrm{mg} / \mathrm{mL})$. The results were expressed as the mg of compound/g HB or plant material. 


\subsection{Determination of Hypoglycemic Potential}

2.6.1. $\alpha$-Glucosidase Inhibitory Assay

Inhibition of $\alpha$-glucosidase by the extracts was performed according to StudzińskaSroka et al. [15], with some modifications. Briefly, $50.0 \mu \mathrm{L}$ of sample solution $(5-40 \mathrm{mg} / \mathrm{mL})$, acarbose $(5-40 \mathrm{mg} / \mathrm{mL})$, chlorogenic acid, gallic acid, protocatechuic acid and rutin as a positive control, $(0.5-20 \mathrm{mg} / \mathrm{mL}), 50.0 \mu \mathrm{L}$ of $0.1 \mathrm{M}$ phosphate buffer $(\mathrm{pH} 6.8)$ and $30.0 \mu \mathrm{L}$ of $\alpha$-glucosidase solution $(0.5 \mathrm{U} / \mathrm{mL})$ were pre-incubated in 96 well plates at $37^{\circ} \mathrm{C}$ for $15 \mathrm{~min}$. Next, $20.0 \mu \mathrm{L}$ of $5 \mathrm{mM}$ p-nitrophenyl- $\alpha$-D-glucopyranoside (pNPG) solution in $0.1 \mathrm{M}$ phosphate buffer ( $\mathrm{pH} 6.8$ ) was added and incubated at $37^{\circ} \mathrm{C}$ for $20 \mathrm{~min}$. The reaction was terminated by adding $100.0 \mu \mathrm{L}$ of sodium carbonate $(0.2 \mathrm{M})$ into the mixture. The absorbance of the liberated p-nitrophenol was measured after $2 \mathrm{~min}$ at $405 \mathrm{~nm}$. The absorbance of enzyme solution without extracts/acarbose served as the control, with total enzyme activity. The absorbance in the absence of the enzyme was used as the blind control. The absorbance of extract/compound solution without enzyme was used as the blank for tested sample. The enzyme inhibition rate (presented for the final concentration of substance in enzymatic reaction) was expressed as a percentage of inhibition and calculated using the following formula:

$$
\text { Inhibitory activity }(\%)=\left[\left(\mathrm{A}_{0}-\mathrm{A}_{1}\right) / \mathrm{A}_{0}\right] \times 100
$$

where $\mathrm{A}_{0}$ is the absorbance of the control ( $100 \%$ enzyme activity), and $\mathrm{A}_{1}$ is the absorbance of the tested sample.

\subsection{2. $\alpha$-Amylase Inhibitory Assay}

The $\alpha$-amylase inhibitory activity of each herbal blends was determined by a spectrophotometric method. In the first step, $20 \mu \mathrm{L}$ of $\alpha$-amylase solution prepared by dissolving in phosphate buffer with $\mathrm{pH}=6.9(4.0 \mathrm{U} / \mathrm{mL})$ and $20 \mu \mathrm{L}$ of the test extract $(80 \mathrm{mg} / \mathrm{mL})$ or acarbose $(0.008 \mathrm{mg} / \mathrm{mL}$, used as a positive control) were preincubated in the 96 -well plate at $37{ }^{\circ} \mathrm{C}$. After $20 \mathrm{~min}, 20 \mu \mathrm{L}$ of previously prepared in warm $0.1 \mathrm{M}$ phosphate buffer ( $\mathrm{pH} 6.9$ ) and $0.5 \%$ starch solution was added to the wells and incubated again for $20 \mathrm{~min}$ at $37^{\circ} \mathrm{C}$. Then, $60 \mu \mathrm{L}$ of color reagent was added to each well. Color reagent was containing $96 \mathrm{mM}$ 3,5-dinitrosalicylic acid solution $(20 \mathrm{~mL}), 5.31 \mathrm{M}$ potassium sodium tartrate solution in $2 \mathrm{M}$ sodium hydroxide $(8 \mathrm{~mL})$, and deionized water $(12 \mathrm{~mL})$. The plate was incubated at $85^{\circ} \mathrm{C}$ for $15 \mathrm{~min}$, then cooled to room temperature, and $80 \mu \mathrm{L}$ of water was added. The measurement of absorbance was carried out at $540 \mathrm{~nm}$ (Multiskan GO 1510, Thermo Fisher Scientific, Vantaa, Finland). Absorbance of the enzyme solution without extracts/acarbose was used as a control for total enzyme activity. Individual blanks containing test herbal blends without the enzyme and starch solution were prepared for correcting the background absorbance. The rate of enzyme inhibition (presented for the final concentration of substance in enzymatic reaction) was expressed as a percentage of inhibition, and calculated using the following formula:

$$
\text { Inhibitory activity }(\%)=\left[\left(\mathrm{A}_{0}-\mathrm{A}_{1}\right) / \mathrm{A}_{0}\right] \times 100
$$

where $A_{0}$ is the absorbance of the control reduced by the sample background $(100 \%$ enzyme activity), and $\mathrm{A}_{1}$ is the absorbance of the tested sample reduced by the sample background.

\subsection{Determination of the Preventive Potential for Type II Diabetes Complications \\ 2.7.1. DPPH and CUPRAC Assays}

The DPPH assay was effected according to [15] with slight modifications. Briefly, $25.0 \mu \mathrm{L}$ of the extract at different concentrations were mixed with $175.0 \mu \mathrm{L}$ of DPPH ${ }^{\bullet}$ solution; then, the reaction mixture was shaken and incubated in the dark at room temperature for $30 \mathrm{~min}$. $\mathrm{DPPH}^{\bullet}$ solutions were freshly prepared for each analysis $(3.9 \mathrm{mg}$ DPPH in $50.0 \mathrm{~mL}$ of $\mathrm{MeOH})$. Absorbance was measured at $517 \mathrm{~nm}$. The control blank contained 
$25.0 \mu \mathrm{L}$ of distilled water and $175.0 \mu \mathrm{L}$ of $\mathrm{DPPH}^{\bullet}$ solution. The inhibition of the $\mathrm{DPPH}^{\bullet}$ radical by the sample was calculated according to the following formula:

$$
\text { DPPH scavenging activity }(\%)=\left[\left(\mathrm{A}_{0}-\mathrm{A}_{1}\right) / \mathrm{A}_{0}\right] \times 100 \%
$$

where $\mathrm{A}_{0}$ is the absorbance of the control, and $\mathrm{A}_{1}$ is the absorbance of the sample. The $\mathrm{IC}_{50}$ values (expressed as final concentration in the sample), i.e., the amount of antioxidant necessary to half of the initial $\mathrm{DPPH}^{\bullet}$ concentration, were used to compare the quality of the antioxidant potency of the studied extracts. A lower absorbance of the reaction mixture indicated a higher free radical scavenging activity.

The CUPRAC (cupric ion reducing antioxidant capacity) assay was effected according to Studzińska-Sroka et al. [15]. The stock solutions of CUPRAC reagent included equal parts of acetate buffer ( $\mathrm{pH} 7.0$ ), $7.5 \mathrm{mM}$ neocuproine solution in $96 \%$ ethanol, and $10.0 \mathrm{mM}$ $\mathrm{CuCl}_{2} \mathrm{xH}_{2} \mathrm{O}$ solution. Briefly, $50.0 \mu \mathrm{L}$ of the extract at different concentrations was mixed with $150.0 \mu \mathrm{L}$ of CUPRAC solution, then shaken and incubated at room temperature for $30 \mathrm{~min}$ in the dark condition. The absorbance was measured at $450 \mathrm{~nm}$ against blank sample (water mixed with CUPRAC solution). The results were expressed as the $\mathrm{IC}_{0.5}$, which corresponds to the concentration (expressed as final concentration in the sample) required to produce absorbance value equal 0.5. A higher absorbance of the reaction mixture indicated a higher antioxidant reducing capacity.

\subsubsection{Determination of $\mathrm{Fe}^{2+}$ Chelating Activity}

The binding of $\mathrm{Fe}^{2+}$ by the extracts was effectuated according to Dinis et al. [16], with some modifications. Briefly, $200.0 \mu \mathrm{L}$ of sample solution or EDTA (as a positive control), at different concentrations, and $10.0 \mu \mathrm{L}$ of $\mathrm{FeCl}_{2} \cdot 4 \mathrm{H}_{2} \mathrm{O}(1 \mathrm{mM})$ were mixed and pre-incubated in 96 well plates at room temperature for $10 \mathrm{~min}$. Afterward, $10 \mu \mathrm{L}$ of ferrozine $(2.5 \mathrm{mM})$ was added and incubated at room temperature for $30 \mathrm{~min}$. The absorbance of the iron (II)-ferrozine complex was measured at $562 \mathrm{~nm}$. The chelating activity (presented for the final concentration of samples) was expressed as a percentage using the following equation:

$$
\text { Chelating activity }(\%)=\left[\left(\mathrm{A}_{0}-\mathrm{A}_{1}\right) / \mathrm{A}_{0}\right] \times 100 \%
$$

where $A_{0}$ is the absorbance of the control, and $A_{1}$ is the absorbance of the sample.

\subsubsection{Determination of Anti-Collagenase Potential}

The collagenase inhibitory activity of each HBs was determined in vitro according to Widodo et al. [17], with some modifications. Briefly, $15.0 \mu \mathrm{L}$ of enzyme, $60 \mu \mathrm{L}$ of tricine buffer ( $\mathrm{pH} 7.5)$, and $30 \mu \mathrm{L}$ of $\mathrm{HB}$ extracts $(10 \mathrm{mg} / \mathrm{mL}$ ) or epigallocatechin gallate (EGCG) $\left(1.0 \mathrm{mg} / \mathrm{mL}\right.$ and $0.1 \mathrm{mg} / \mathrm{mL}$, positive control) were mixed and incubated at $37^{\circ} \mathrm{C}$ for $20 \mathrm{~min}$. Next, $20 \mu \mathrm{L}$ of FALGPA $(0.5 \mathrm{mM})$ was added, and they were measured immediately at $325 \mathrm{~nm}$ using the plate reader (Multiskan GO 1510, Thermo Fisher Scientific, Vantaa, Finland), following the addition of the substrate, and then again after $20 \mathrm{~min}$ of incubation at $37^{\circ} \mathrm{C}$. The collagenase inhibition rate (presented for the final concentration of substance in enzymatic reaction) expressed as a percentage of inhibition was calculated using the following formula:

$$
\text { Inhibitory activity }(\%)=\left[\left(\mathrm{A}_{0}-\mathrm{A}_{1}\right) / \mathrm{A}_{0}\right] \times 100
$$

where $\mathrm{A}_{0}$ is the absorbance of the control ( $100 \%$ enzyme activity), and $\mathrm{A}_{1}$ is the absorbance of the tested sample.

\subsection{Statistical Analysis}

Analyses of determination of total flavonoids and phenolic compounds, as well as biological activity, were performed in six replicates; HPLC analysis was performed in three replicates. Results were expressed as means \pm SD. 


\section{Results}

\subsection{Phytochemical Characterization of Herbal Blends}

The examined herbal tea blends have a diverse composition of plant ingredients (Table 1). Thus, they were characterized by diverse content of polyphenolic compounds. Our results showed that the examined herbal infusions are characterized by different total polyphenol and flavonoid contents (Table 2). The highest total polyphenol content, determined for HB5, HB1, and HB6 (16.06, 14.94, and $13.97 \mathrm{mg} \mathrm{GAE/g} \mathrm{HB,} \mathrm{respectively),} \mathrm{was}$ correlated with a high content of flavonoids $(2.23,3.06$, and $2.03 \mathrm{mg}$ QE/g HB, respectively). Interestingly, although HB2 had also high total polyphenols content (15.30 mg GAE/g HB), no such correlation was noted in this case (Table 2).

Table 2. Content of polyphenols (TPC) and flavonoids (TFC) and their daily dose in the tested extracts from herbal tea blends.

\begin{tabular}{ccccc}
\hline & \multicolumn{2}{c}{ Content of Active Substances } & \multicolumn{2}{c}{$\begin{array}{c}\text { Content of Active Substances in the Daily Dose } \\
\text { Recommended by the Manufacturer }\end{array}$} \\
\cline { 2 - 5 } Herbal Blend & $\begin{array}{c}\text { TPC } \\
\text { (mg GAE/g HB) }\end{array}$ & $\begin{array}{c}\text { TFC } \\
\text { (mg QE/g HB) }\end{array}$ & $\begin{array}{c}\text { Polyphenols } \\
\text { (mg/day) }\end{array}$ & $\begin{array}{c}\text { Flavonoids } \\
\text { (mg/day) }\end{array}$ \\
\hline HB1 & $14.94 \pm 0.24$ & $3.06 \pm 0.05$ & 89.64 & 18.36 \\
HB2 & $15.30 \pm 0.30$ & $1.30 \pm 0.06$ & 61.20 & 5.20 \\
HB3 & $11.89 \pm 0.36$ & $1.43 \pm 0.05$ & 35.67 & 4.29 \\
HB4 & $3.83 \pm 0.17$ & $0.56 \pm 0.06$ & 30.64 & 4.48 \\
HB5 & $16.06 \pm 0.63$ & $2.23 \pm 0.03$ & 96.36 & 13.38 \\
HB6 & $13.97 \pm 0.53$ & $2.03 \pm 0.03$ & 83.82 & 12.18 \\
HB7 & $10.92 \pm 0.42$ & $1.08 \pm 0.07$ & 98.28 & 9.72 \\
\hline
\end{tabular}

HB: herbal blend; GAE: gallic acid equivalents; QE: quercetin equivalents.

To complete the total compounds analysis results, we examined in the tested infusions some polyphenols' contents (chlorogenic acid, gallic acid, protocatechuic acid, rutin), considered essential for antidiabetic activity [18]. The obtained results showed that the amount of selected compounds is varied in the investigated HBs (Table 3), with predomination of chlorogenic and gallic acids. Both protocatechuic acid and rutin were present in the samples in smaller amounts.

Table 3. Content of selected polyphenolic compounds in herbal blends.

\begin{tabular}{ccccc}
\hline \multirow{2}{*}{ Herbal Blend } & \multicolumn{3}{c}{$\begin{array}{c}\text { Content of Selected Polyphenolic Compounds } \\
\text { (mg/g Herbal Blend) }\end{array}$} \\
\cline { 2 - 5 } & Chlorogenic Acid & Gallic Acid & Protocatechuic Acid & Rutin \\
\hline HB1 & $1.490 \pm 0.057$ & $0.275 \pm 0.009$ & $0.060 \pm 0.010$ & $0.236 \pm 0.015$ \\
HB2 & $0.474 \pm 0.026$ & $0.079 \pm 0.007$ & $0.040 \pm 0.010$ & $0.071 \pm 0.007$ \\
HB3 & $0.722 \pm 0.040$ & $0.046 \pm 0.003$ & n.a. & $0.058 \pm 0.010$ \\
HB4 & $0.079 \pm 0.009$ & n.a. & $0.070 \pm 0.010$ & $0.043 \pm 0.006$ \\
HB5 & $0.407 \pm 0.028$ & $0.462 \pm 0.014$ & n.a. & $0.029 \pm 0.008$ \\
HB6 & $0.107 \pm 0.015$ & $0.363 \pm 0.021$ & $0.147 \pm 0.015$ & n.a. \\
HB7 & $1.896 \pm 0.143$ & $0.066 \pm 0.009$ & n.a. & $0.100 \pm 0.023$ \\
\hline
\end{tabular}

n.a.: not active.

\subsection{Determination of Hypoglycemic Potential}

$\alpha$-glucosidase and $\alpha$-amylase are some of the key enzymes involved in carbohydrate metabolism, which digest oligosaccharides (disaccharides and polysaccharides) or other complex carbohydrates into monosaccharides (glucose) [7]. By inhibiting the activity of these enzymes, the digestion of carbohydrates and the absorption of glucose in the small intestine are blocked. 
We evaluated the $\alpha$-glucosidase inhibition potential of HBs at four different concentrations $(1.7,3.3,6.7$, and $13.3 \mathrm{mg} / \mathrm{mL})$. The results indicate that the activity of the tested extracts was dose dependent. HB1, HB5, HB6, and HB7 showed the strongest inhibition of the enzyme (Table 4). It is worth noting that in the lowest tested concentration (1.7 mg/mL), only HB5 and HB7 inhibited the enzyme comparable to acarbose used at the same concentration $(93.65 \%, 86.97 \%$, and $80.83 \%$, respectively) (Table 4). Additionally, the inhibitory activity of compounds detected in the tested HBs (chlorogenic acid, gallic acid, as well as protocatechuic acid, and rutin), was tested. For the most active compounds (chlorogenic acid and rutin), the tested concentrations were lower than those for the infusions $(0.17 \mathrm{mg} / \mathrm{mL}$ and $0.3 \mathrm{mg} / \mathrm{mL})$. However, gallic and protocatechuic acids acted much weaker, and only the concentration of $6.7 \mathrm{mg} / \mathrm{mL}$ allowed to observe their inhibitory effect on the tested enzyme. The results are presented in Table 4.

Table 4. Inhibition of $\alpha$-glucosidase activity by the infusions from herbal blends.

\begin{tabular}{|c|c|c|c|c|}
\hline \multirow{3}{*}{ Herbal Blend } & \multicolumn{4}{|c|}{ Inhibition of $\alpha$-Glucosidase Activity [\%] } \\
\hline & \multicolumn{4}{|c|}{ Concentration } \\
\hline & $1.7 \mathrm{mg} / \mathrm{mL}$ & $3.3 \mathrm{mg} / \mathrm{mL}$ & $6.7 \mathrm{mg} / \mathrm{mL}$ & $13.3 \mathrm{mg} / \mathrm{mL}$ \\
\hline HB1 & $35.26 \pm 1.11$ & $83.02 \pm 1.72$ & $92.82 \pm 0.52$ & $98.84 \pm 1.48$ \\
\hline HB2 & $6.73 \pm 1.23$ & $12.43 \pm 2.28$ & $44.60 \pm 1.03$ & $68.49 \pm 4.69$ \\
\hline HB3 & $6.91 \pm 0.80$ & $17.86 \pm 5.81$ & $29.70 \pm 1.12$ & $57.30 \pm 5.55$ \\
\hline HB4 & $2.87 \pm 0.95$ & $8.83 \pm 0.50$ & $17.13 \pm 2.00$ & $37.38 \pm 3.59$ \\
\hline HB5 & $93.65 \pm 1.11$ & $98.06 \pm 0.90$ & $99.78 \pm 0.24$ & 100.00 \\
\hline HB6 & $48.66 \pm 3.51$ & $73.71 \pm 0.55$ & $81.81 \pm 1.78$ & $88.14 \pm 1.14$ \\
\hline HB7 & $86.97 \pm 5.63$ & $97.27 \pm 0.37$ & $99.82 \pm 0.26$ & $99.22 \pm 0.94$ \\
\hline Acarbose & $80.83 \pm 1.02$ & $88.07 \pm 0.77$ & $91.98 \pm 0.17$ & $93.73 \pm 0.03$ \\
\hline \multirow{2}{*}{$\begin{array}{c}\text { Active } \\
\text { Compound }\end{array}$} & \multicolumn{4}{|c|}{ Concentration } \\
\hline & $0.17 \mathrm{mg} / \mathrm{mL}$ & $0.33 \mathrm{mg} / \mathrm{mL}$ & $3.3 \mathrm{mg} / \mathrm{mL}$ & $6.7 \mathrm{mg} / \mathrm{mL}$ \\
\hline $\begin{array}{l}\text { Chlorogenic acid } \\
\text { Gallic acid }\end{array}$ & $\begin{array}{c}46.44 \pm 1.02 \\
\text { n.d. }\end{array}$ & $\begin{array}{c}81.35 \pm 3.34 \\
\text { n.d. }\end{array}$ & $\begin{array}{c}\text { n.d. } \\
18.00 \pm 5.09\end{array}$ & $\begin{array}{c}\text { n.d. } \\
99.65 \pm 2.34\end{array}$ \\
\hline $\begin{array}{c}\text { Protocatechuic } \\
\text { acid }\end{array}$ & n.d. & n.d. & $0.46 \pm 1.42$ & $99.99 \pm 0.13$ \\
\hline Rutin & $65.33 \pm 3.42$ & $97.07 \pm 0.55$ & n.d. & n.d. \\
\hline
\end{tabular}

The $\alpha$-amylase inhibition of HBs was performed at $27.6 \mathrm{mg} / \mathrm{mL}$ concentration. Our study demonstrated that the most potent inhibitor is HB7, and the weaker inhibitors are HB5, HB6, HB2, and HB1, respectively. HB3 and HB4 exhibit no inhibitory effect. However, the activity of tested HBs is significantly lower than that of acarbose. The results are presented in Table 5 .

Table 5. Inhibition of $\alpha$-amylase activity by the infusions from herbal blends.

\begin{tabular}{ccc}
\hline & \multicolumn{2}{c}{ Inhibition of $\alpha$-Amylase Activity [\%] } \\
\cline { 2 - 3 } Herbal Blend & \multicolumn{2}{c}{ Concentration } \\
\cline { 2 - 3 } & $\mathbf{2 6 . 7} \mathbf{~} \mathbf{~ g / \mathbf { m L }}$ & $\mathbf{0 . 0 0 2 6 7} \mathbf{~ m g / m L}$ \\
\hline HB1 & $3.62 \pm 4.95$ & n.d. \\
HB2 & $4.02 \pm 3.96$ & n.d. \\
HB3 & $0.31 \pm 0.77$ & n.d. \\
HB4 & $0.13 \pm 0.31$ & n.d. \\
HB5 & $20.14 \pm 5.94$ & n.d. \\
HB6 & $5.62 \pm 7.32$ & n.d. \\
HB7 & $96.16 \pm 6.00$ & n.d. \\
Acarbose & n.d. & $28.11 \pm 2.80$ \\
\hline
\end{tabular}




\subsection{Determination of the Preventive Potential for Type II Diabetes Complications}

\subsubsection{In Vitro Antioxidant Activity}

Oxidative stress is responsible for the development of diabetes complications. Therefore, antioxidant activity is of great importance in preventing adverse complications of this disease. To test the antioxidant activity of HBs' extracts two complementary methods were chosen: the $\mathrm{DPPH}^{\bullet}$ radical, characterizing the ability of the tested sample to scavenge free radicals, and the CUPRAC reagent, assessing the reducing properties of metal ions.

The results of the HBs infusions antioxidant activity analysis showed that among the tested preparations, the most active was HB1 $\left(\mathrm{IC}_{50} \mathrm{DPPH}=310.03 \mu \mathrm{g} / \mathrm{mL}\right.$, $\mathrm{IC}_{0.5}$ CUPRAC $\left.=368.15 \mu \mathrm{g} / \mathrm{mL}\right)$ and HB5 $\left(\mathrm{IC}_{50} \mathrm{DPPH}=350.52 \mu \mathrm{g} / \mathrm{mL}\right.$, $\mathrm{IC}_{0.5}$ CUPRAC $=344.43 \mu \mathrm{g} / \mathrm{mL}$ ) herbal infusions. However, the effect of both tested water extracts was weaker than that of vitamin $\mathrm{C}$, used as a standard $\left(\mathrm{IC}_{50} \mathrm{DPPH}=7.62 \mu \mathrm{g} / \mathrm{mL}\right.$ and $\mathrm{IC}_{0.5}$ CUPRAC $=14.64 \mu \mathrm{g} / \mathrm{mL}$ ). $\mathrm{HB} 4$ (bean pod, nettle herb or leaf, nettle rhizome, dandelion root) performed much weaker than others, which indicates its poor antioxidant properties. The scavenging capacity of DPPH free radicals or the reducing properties of other tested preparations ranged from $\mathrm{IC}_{50} \mathrm{DPPH}=361.17 \mu \mathrm{g} / \mathrm{mL}$ to IC $50 \mathrm{DPPH}=744.74 \mu \mathrm{g} / \mathrm{mL}$, and from $\mathrm{IC}_{0.5}$ CUPRAC $=409.92 \mu \mathrm{g} / \mathrm{mL}$ to $\mathrm{IC}_{0.5}$ CUPRAC $=686.43 \mu \mathrm{g} / \mathrm{mL}$ (Table 6). The scavenging capacity of DPPH free radicals or the reducing properties of HB2 and HB3 was presented as approximately 2-times lower to the highest active herbal infusions (Table 6). The HB4 was characterised by the worst activity.

Table 6. Antioxidant activity of tested herbal infusions.

\begin{tabular}{|c|c|c|}
\hline \multirow[b]{2}{*}{ Herbal Blend } & \multicolumn{2}{|c|}{ Antioxidant Activity } \\
\hline & $\begin{array}{c}\mathrm{DPPH}^{\bullet} \\
\left(\mathrm{IC}_{50} \mu \mathrm{g} / \mathrm{mL}\right)^{1}\end{array}$ & $\begin{array}{c}\text { CUPRAC } \\
\left(\mathrm{IC}_{0.5} \mu \mathrm{g} / \mathrm{mL}\right)^{1}\end{array}$ \\
\hline HB1 & 310.03 & 368.15 \\
\hline HB2 & 715.58 & 686.43 \\
\hline HB3 & 744.74 & 680.14 \\
\hline HB4 & 1336.03 & 931.00 \\
\hline HB5 & 350.52 & 344.43 \\
\hline HB6 & 394.76 & 409.92 \\
\hline HB7 & 361.17 & 591.50 \\
\hline vitamin $C$ & 7.62 & 14.64 \\
\hline
\end{tabular}

${ }^{1}$ Concentration was expressed as $\mathrm{mg}$ of herbal blend in the tested sample.

The relationship between the decompartmentalized metal ions and diabetic complications is the content of many scientific works [19]. To know the potential of herbal infusions in this area, we assessed the chelating properties of $\mathrm{Fe}^{2+}$ ions by HBs water extracts, using a ferrozine in vitro test. The obtained results indicate a dose-dependent, robust activity of the studied samples. The water extracts of HB3, HB4, and HB6 showed the most potent effect, showing $>50 \%$ of chelating activity at the lowest concentration tested $(0.45 \mathrm{mg} / \mathrm{mL})$, which was also 20 times lower than when taken in the form of an infusion. The chelating ability close to $90 \%$ was achieved by HB1-HB6 blends for the concentration four times lower $(2.3 \mathrm{mg} / \mathrm{mL})$ than the concentration of the ready-to-drink herbal infusion (Table 7). The only herbal blend that showed no activity (at low concentrations) or little activity at the highest concentrations tested was HB7 (Table 7). This result contrasted with HB7's high anti-radical activity, as well as very good $\alpha$-glucosidase and $\alpha$-amylase inhibition properties and collagenase inhibition. 
Table 7. Chelating activity of tested herbal infusions.

\begin{tabular}{|c|c|c|c|c|c|}
\hline \multirow{3}{*}{$\begin{array}{c}\text { Herbal } \\
\text { Blend }\end{array}$} & \multicolumn{5}{|c|}{ Chelating Activity $\mathrm{Fe}^{2+}[\%]$} \\
\hline & \multicolumn{5}{|c|}{ Concentration } \\
\hline & $0.45 \mathrm{mg} / \mathrm{mL}$ & $0.9 \mathrm{mg} / \mathrm{mL}$ & $2.3 \mathrm{mg} / \mathrm{mL}$ & $4.6 \mathrm{mg} / \mathrm{mL}$ & $9.1 \mathrm{mg} / \mathrm{mL}$ \\
\hline HB1 & $43.92 \pm 1.34$ & $70.36 \pm 7.02$ & $92.01 \pm 0.68$ & $95.55 \pm 0.63$ & $99.34 \pm 1.38$ \\
\hline HB2 & $27.53 \pm 3.05$ & $51.16 \pm 1.80$ & $89.49 \pm 2.45$ & $89.85 \pm 1.75$ & $87.98 \pm 0.10$ \\
\hline HB3 & $56.38 \pm 5.93$ & $89.47 \pm 1.74$ & $96.58 \pm 0.79$ & $96.15 \pm 1.23$ & $97.11 \pm 0.57$ \\
\hline HB4 & $62.81 \pm 1.72$ & $88.31 \pm 0.35$ & $94.05 \pm 0.48$ & $94.35 \pm 0.28$ & $93.21 \pm 0.53$ \\
\hline HB5 & $34.15 \pm 1.14$ & $67.49 \pm 1.90$ & $94.11 \pm 0.58$ & $94.65 \pm 0.42$ & $97.15 \pm 1.64$ \\
\hline HB6 & $62.10 \pm 3.16$ & $91.10 \pm 1.17$ & $98.38 \pm 0.54$ & $98.41 \pm 1.06$ & $99.44 \pm 2.99$ \\
\hline HB7 & n.a. & n.a. & $5.91 \pm 4.33$ & $9.43 \pm 4.72$ & $9.33 \pm 3.19$ \\
\hline \multirow{2}{*}{ Reference } & \multicolumn{5}{|c|}{ Concentration } \\
\hline & $0.01 \mathrm{mg} / \mathrm{mL}$ & $0.023 \mathrm{mg} / \mathrm{mL}$ & $0.045 \mathrm{mg} / \mathrm{mL}$ & - & - \\
\hline EDTA & $66.50 \pm 2.20$ & $99.59 \pm 0.57$ & $100.24 \pm 0.20$ & - & - \\
\hline
\end{tabular}

\subsubsection{In Vitro Anti-Inflammatory Activity}

Our research has shown that the mixtures used to prepare infusions taken in the early stages of diabetes can inhibit collagenase, and the activity was recorded at a concentration that is intended for direct consumption. The HB5 mixture most strongly inhibited the enzyme $(28.79 \%)$. The other blends, with the exception of HB3, which did not show any activity at the tested concentration, were less effective (8.47-21.46\%). Despite the reported activity, the action level of the most active mixture was three times lower than the standard's 10-fold lower concentration (EGCG) (Table 8).

Table 8. Inhibition of collagenase activity by the infusions from herbal blends.

\begin{tabular}{|c|c|c|c|}
\hline \multirow{3}{*}{ Herbal Blend } & \multicolumn{3}{|c|}{ Inhibition of Collagenase Activity [\%] } \\
\hline & \multicolumn{3}{|c|}{ Concentration } \\
\hline & $2.4 \mathrm{mg} / \mathrm{mL}$ & $0.24 \mathrm{mg} / \mathrm{mL}$ & $0.024 \mathrm{mg} / \mathrm{mL}$ \\
\hline HB1 & $16.22 \pm 3.22$ & n.d. & n.d. \\
\hline HB2 & $21.46 \pm 3.04$ & n.d. & n.d. \\
\hline HB3 & n.a. & n.d. & n.d. \\
\hline HB4 & $8.47 \pm 4.66$ & n.d. & n.d. \\
\hline HB5 & $28.79 \pm 2.65$ & n.d. & n.d. \\
\hline HB6 & $13.68 \pm 6.21$ & n.d. & n.d. \\
\hline HB7 & $18.42 \pm 7.68$ & n.d. & n.d. \\
\hline EGCG & n.d. & $84.30 \pm 8.83$ & $35.78 \pm 5.52$ \\
\hline
\end{tabular}

n.a.: not active; n.d.: not determined; EGCG: epigallocatechin gallate.

\subsection{Summary of Antidiabetic Potential of Tested Herbal Blends}

Finally, to better visualize and compare the obtained results, we performed the data as a star diagram (Figure 1). According to the presented relationship, HB7 and HB5 have the highest antidiabetic potential. Both of them were characterized by high hypoglycemic properties, especially by inhibiting $\alpha$-glucosidase, and also, but in a moderate way, $\alpha$-amylase. HB5 is also characterized by preventive potential against diabetic complications, due to its highest antioxidant capacity and the best collagenase inhibition properties. Another HBs, whose biological properties (at least 2 out of 3 examined) suggest an interesting preventive potential, are HB6, HB1, and HB4, respectively, for which the chelating and antioxidant potential were noticeable. 


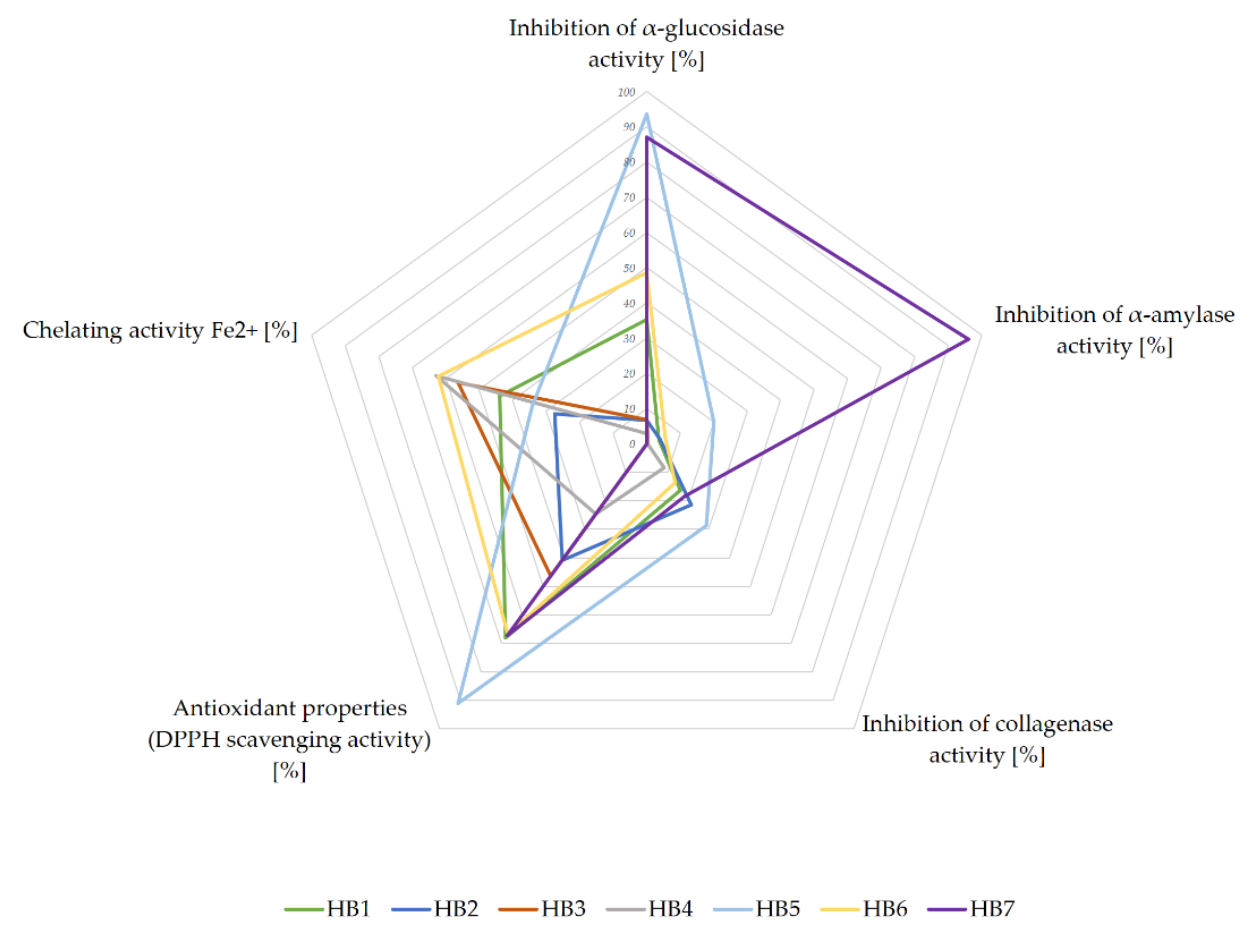

Figure 1. The antidiabetic potential of herbal blends 1-7 (HB 1-7), presented graphically, taking into account the measured biological properties expressed in \%. The graph was made for the concentrations: inhibition of $\alpha$-glucosidase activity $1.7 \mathrm{mg} / \mathrm{mL}$; inhibition of $\alpha$-amylase activity $26.7 \mathrm{mg} / \mathrm{mL}$; inhibition of collagenase activity $2.4 \mathrm{mg} / \mathrm{mL}$; antioxidant potential - DPPH assay $0.625 \mathrm{mg} / \mathrm{mL}$; chelating activity $0.45 \mathrm{mg} / \mathrm{mL}$.

\section{Discussion}

Diabetes is a metabolic disease that, if left untreated, leads to serious complications in the form of retinopathy, neuropathy, or nephropathy. Apart from the standard pharmacotherapy, the use of herbal drugs seems to be an interesting and complementary strategy to prevent or alleviate the symptoms of the disease. However, the effectiveness of multicomponent HBs is often not scientifically proven and the mechanism of their activity also needs to be clarified.

Our in vitro study evaluated the antidiabetic potential of herbal infusions to prevent and support the treatment of early stages of type II diabetes. The key question is whether the extraction with hot water is effective enough to receive biological activity of the active ingredients. The products selected for our study contained pharmaceutical raw materials (according to the European Pharmacopoeia: dandelion root, dandelion herb with root, couch grass rhizome, nettle leaf, cinnamon) [20], or the components of dietary supplements (chokeberry fruit, blackcurrant fruit, apple fruit, buckwheat husk, mulberry leaf, bean pod).

The antidiabetic mechanisms of polyphenols include the possibility of inhibiting digestive enzymes (e.g., $\alpha$-amylase or $\alpha$-glucosidase), which are essential in limiting the absorption of sugars [21]. Polyphenols have also been reported as stimulants of intestinal peptides secretion that can stimulate insulin secretion in the pancreas [22]. The data confirm the ability of polyphenolic compounds to stimulate insulin production from $\beta$-cells of the pancreas, increasing glycolysis and reducing gluconeogenesis, [23,24], scavenging free radicals, and chelating metals, which translates into anti-inflammatory activity [25].

The mentioned antidiabetic potential of polyphenolic compounds prompted us to conduct phytochemical characterization of the studied herbal infusions. HBs containing mulberry leaves (HB1, HB2, HB5, HB6) had high polyphenols and total flavonoids content. The highest TFC value was for single-component HB1 with Mori albi folium (mulberry leaves) (Table 2). Some literature data confirm that flavonoids are the important fraction of natural substances in the mulberry leaves, responsible for its biological activity [26]. 
More detailed analysis showed that all the tested herbal infusions contained chlorogenic acid (Table 3), the compound of high importance in terms of regulating blood glucose level [27] and alleviating metabolic syndrome symptoms [26,28] in a number of in vitro and in vivo studies. The therapeutic efficacy of chlorogenic acid, both as a pure substance and in the form of an extract was also proven in some clinical studies [29]. The highest content of chlorogenic acid was determined for HB1, with mulberry leaves as the only ingredient (Table 3). Six out of the seven studied HBs contained gallic acid, whose antidiabetic potential has been supported by various studies [30,31]. The highest content of this phenolic compound was observed in the herbal infusions containing mulberry leaves (HB1, HB5, HB6), which is consistent with previous literature data [32]. Protocatechuic acid and rutin were presented in the tested HBs in small amounts (Table 3). The low concentration of rutin is due to the tested extracts' water nature, and the low solubility of the flavonoid in water $[33,34]$.

The inhibition of $\alpha$-glucosidase is a known mechanism of hypoglycemic activity. The chemical glucosidase inhibitors available on the pharmaceutical market are characterized by many side effects associated with gastrointestinal discomforts, such as abdominal distention, vomiting, and diarrhea [35], while some $\alpha$-glucosidase inhibitors of plant origin can show hypoglycemic activity without the appearance of such side effects [36]. Therefore, we tested herbal infusions from HBs for their ability to inhibit $\alpha$-glucosidase and $\alpha$-amylase. Our study showed the $\alpha$-glucosidase and $\alpha$-amylase inhibitory potential of HBs. We noticed these properties are probably connected with the high quantity in all tested herbal infusions of phenolic compounds (total polyphenols and flavonoids, as well as individual phenolic acids: chlorogenic acid, gallic acid, protocatechuic acid, and rutin). We demonstrated significant inhibitory activity of examined pure substances for $\alpha$-glucosidase, which is consistent with the results of other authors [18]. According to literature data, the active compounds we detected in the herbal infusions exhibit an inhibitory effect on $\alpha$-amylase activity [37,38].

Subsequently we noticed that the potency of tested HBs in $\alpha$-glucosidase and $\alpha$ amylase inhibition is stronger with the increased amount of cinnamon in bark their composition, which was especially observed for HB5 and HB6 (Tables 4 and 5). We observed that HB5 containing 30\% of cinnamon bark showed $98.06 \%$ of $\alpha$-glucosidase inhibition at the concentration $3.3 \mathrm{mg} / \mathrm{mL}$, while $5 \%$ of the bark in HB6 presented $73.71 \%$ of inhibitory activity at the same concentration. A similar effect was noticed for $\alpha$-amylase inhibition, with HB5 showing $20.14 \%$ of enzyme inhibition in concentration $26.7 \mathrm{mg} / \mathrm{mL}$, while HB6 presented $5.62 \%$ of enzyme inhibition in concentration $8.0 \mathrm{mg} / \mathrm{mL}$. The strong ability to inhibit $\alpha$-glucosidase and $\alpha$-amylase by cinnamon bark has been described by other authors $[39,40]$. Moreover, an additive effect on the inhibition of intestinal enzymes ( $\alpha$-glucosidase and $\alpha$-amylase) was demonstrated for cinnamon bark combined with acarbose [40]. The cinnamon bark phenolic acids' synergism with metformin was also observed [41]. The studies shown that the antidiabetic potential of cinnamon bark was highly correlated with their proanthocyanidin and condensed tannin [42]. Moreover the presence of flavonoids in mulberry leaves as the constituent of HB5 and HB6 water herbal infusions favors inhibiting the enzyme activity [43]. However, this issue needs further studies to explain the mutual relationships between the components of the herbal blends and the observed activity.

The HB7, containing anthocyanins-rich plants in, indicated high potential to inhibit the $\alpha$-glucosidase and $\alpha$-amylase enzymes. Sui et al. [44] demonstrated in vitro inhibitory effects of anthocyanins against pancreatic $\alpha$-amylase verified, also by an in silico molecular docking study. Barik et al. [45] suggest anthocyanins regulate postprandial hyperglycemia not solely by inhibiting $\alpha$-glucosidase, but also as a result of modulating glucose uptake and sugar transporters. Moreover, Boath et al. [46] show that the blackcurrant, constituting the important part of HB7, has strong ability to inhibit $\alpha$-glucosidase. What is more, it synergistic effect with acarbose was also observed [46]. It is also known that both 
chokeberry and blackcurrant fruit contain active flavonoids and tannins, which affect the antidiabetic potential by different mechanisms, including inhibition of the enzymes [12].

Cells' oxidative stress contributes to the development of insulin resistance and also causes changes in the walls of blood vessels, which, in the conditions of increased hyperglycemia, leads to complications of diabetes [47]. Conducted experiments show that herbal infusions can exhibit antioxidant properties that can prevent diabetes complications and protect, among others, before the oxidation of unsaturated lipids and promoting oxidative damage at different levels.

In our study, high antioxidant activity (however, weaker than vitamin $\mathrm{C}$ used as a standard) was noted for most of the herbal infusions prepared from tested HBs (Table 6). What is more, these results correlated with the high total polyphenols or total flavonoid contents (Table 2), as well as with high content of chlorogenic and gallic acid, compared to other tested infusions (Table 3). Moreover, the anthocyanins and condensed proanthocyanidins, compounds of blackcurrant or chokeberry fruits [48] (the components of HB7), could explain the antioxidant potential of HB7. The HB5 and HB6, in addition to mulberry leaves, also contained cinnamon bark, a valuable source of antioxidant and hypoglycemic compounds [49]. Our research indicated no relationship between the increased content of cinnamon bark in the two-component blends (mulberry leaf and cinnamon bark) and their antioxidant properties.

The ability to chelate metal ions increases total antioxidant potential [50] which may result in a reduction in the concentration of the catalyzing transition metal in lipid peroxidation. This approach determined the emergence of therapies in which the use of substances can chelate transition metals aided in the treatment of chronic hyperglycemia [51]. The chelating abilities of metals are mainly due to polyphenol compounds [52], including chlorogenic, gallic, or protocatechuic acids and flavonoids [42,52,53]. For HB1, HB5, and HB6, the dominant component was the polyphenol-rich mulberry leaves, which can influence high chelating abilities. The chelating properties of cinnamon bark (a component of HB5 and HB6) have been proven for cinnamaldehyde present in the raw material in large amounts [54]. Our research shows that quite possibly not only polyphenols have an impact on the assessed activity. The composition of the chelating active HB3 and HB4 blends suggests that the large amounts of Phaseoli pericarpium (among others sources of amino acids, chromium salts, guanidine derivatives, triterpenes, condensed tannins, sterols, and small quantities of polyphenols) [55,56] and aerial parts from Urtica dioica (besides polyphenols, the source of amines, amino acids, terpenes, organic acids, sterols) [57,58] can affect the increase of the ability of chelation. Carrasco-Castilla et al. [59] state that peptide fractions isolated from Phaseolus vulgaris showed the ability to chelate iron ions in vitro. According to Drużyńska et al. [56], Phaseoli pericarpium's condensed tannins increase the chelation of transition metal ions. The high capacity of aqueous extracts from aerial parts of Urtica dioica to chelate iron ions was demonstrated by Gülçin et al. [60].

The results of the analysis concerning HB7, active in other trials, but with the weakest chelating ability among the tested HBs, seem interesting. This may be explained by the substantial amounts of dried chokeberry and blackcurrant fruits, rich in anthocyanins, the reduced chelating ability of which is related to the presence of one- or two-metal binding sites, when compared the other polyphenols, with three or four metal-binding sites [52].

Collagenase, belonging to the group of metalloproteinases, is an enzyme whose activity in tissues increases significantly in diabetic disease [61,62], that results in the development of complications related to the disturbance of collagen metabolism in periodontal diseases [61], vascular complications [63-65], or inflammation of the gastrointestinal tract [62]. The compounds of plant origin, both as pure substances and in the form of plant extracts, can effectively inhibit metalloproteinases [66,67], which was especially proven for flavonoids (including rutin and potent inhibitor of collagenase EGCG [68]), phenolic acids (in chlorogenic acid and gallic acid), anthocyanins (including from blackcurrant (delphinidin derivatives)) or procyanidins [69]. Moreover, collagenase-inhibiting properties were noted for extracts from nettle [70], and black chokeberries [71], present in the examined 
HBs. Our results indicated moderate anti-collagenase activity of all the tested HBs, with the exception of HB3. Therefore, it seems that the regular consumption of herbal infusions may help in the likely consequences of hyperglycemia, such as inflammation of the oral cavity or further digestive tract sections. Moreover, it should be noted that the absorption capacity of the active substances present in HBs also provides the possibility of systemic action, which increases the effectiveness of the prevention of diabetic complications. However, this requires further research.

\section{Conclusions}

We have proven that the extraction with hot water during the preparation of herbal infusions allows for the achievement of adequate concentrations of phenolic acids, flavonoids, and other probably synergistic compounds to provide the potential for hypoglycemic action. The examined herbal blends demonstrated a multidirectional mechanism of action, and are helpful in the prevention or treatment of early stages not only of diabetes, but also other metabolic diseases leading to several complications. With the obtained results, we can recommend herbal infusions containing mulberry leaves, especially those containing cinnamon bark or anthocyanins, to support the treatment of diabetes type II and to prevent its grave implications.

Author Contributions: Conceptualization, E.S.-S.; methodology, E.S.-S. and A.G. (Agnieszka Galanty); formal analysis, M.W., E.S.-S., A.G. (Agnieszka Galanty), A.G. (Anna Gościniak); investigation, E.S.-S., M.W., A.G. (Agnieszka Galanty), A.G. (Anna Gościniak); resources, J.C.-P., A.G. (Agnieszka Galanty) and E.S.-S.; data curation, M.W., A.G. (Agnieszka Galanty), A.G. (Anna Gościniak), E.S.-S.; writingoriginal draft preparation, M.W., E.S.-S., J.C.-P.; writing-review and editing, E.S.-S., J.C.-P., A.G. (Agnieszka Galanty), A.G. (Anna Gościniak), M.D.-M. and M.K.; visualization E.S.-S. and J.C.-P.; supervision, E.S.-S. and J.C.-P.; project administration, E.S.-S.; funding acquisition, E.S.-S., J.C.-P. All authors have read and agreed to the published version of the manuscript.

Funding: This research was funded by the grant from Minister of Education and Science, Poland: SKN/SP/496064/2021.

Institutional Review Board Statement: Not applicable.

Informed Consent Statement: Not applicable.

Data Availability Statement: The data supporting reported results were be found in: Department of Pharmacognosy, Poznan University of Medical Sciences and Department of Pharmacognosy, Faculty of Pharmacy, Jagiellonian University Medical College.

Conflicts of Interest: The authors declare no conflict of interest.

\section{References}

1. World Health Organization. Diabetes. Available online: https://www.who.int/news-room/fact-sheets/detail/diabetes (accessed on 4 November 2021).

2. Wierusz-Wysocka, B.; Araszkiewicz, A.; Schlaffke, J. Końcowe produkty glikacji-Nowy biomarker cukrzycy i jej powikłań? Clin. Diabetol. 2013, 2, 96-103.

3. Abdulmalik, H.; Tadiwos, Y.; Legese, N. Assessment of drug-related problems among type 2 diabetic patients on follow up at Hiwot Fana Specialized University Hospital, Harar, Eastern Ethiopia. BMC Res. Notes 2019, 12, 771. [CrossRef] [PubMed]

4. Latek, D.; Rutkowska, E.; Niewieczerzal, S.; Cielecka-Piontek, J. Drug-induced diabetes type 2: In silico study involving class B GPCRs. PLoS ONE 2019, 14, e0208892. [CrossRef]

5. Pasznik, P.; Rutkowska, E.; Niewieczerzal, S.; Cielecka-Piontek, J.; Latek, D. Potential off-target effects of beta-blockers on gut hormone receptors: In silico study including GUT-DOCK-A web service for small-molecule docking. PLoS ONE 2019, 14, e0210705. [CrossRef] [PubMed]

6. Deacon, C.F.; Lebovitz, H.E. Comparative review of dipeptidyl peptidase-4 inhibitors and sulphonylureas. Diabetes Obes. Metab. 2016, 18, 333-347. [CrossRef]

7. Sonia, T.A.; Sharma, C.P. Oral Delivery of Insulin; Elsevier: Cambridge, UK, 2014; ISBN 1908818689.

8. Stamataki, N.S.; Yanni, A.E.; Karathanos, V.T. Bread making technology influences postprandial glucose response: A review of the clinical evidence. Br. J. Nutr. 2017, 117, 1001-1012. [CrossRef] [PubMed]

9. Babu, P.V.A.; Liu, D.; Gilbert, E.R. Recent advances in understanding the anti-diabetic actions of dietary flavonoids. J. Nutr. Biochem. 2013, 24, 1777-1789. [CrossRef] 
10. Purohit, P.; Mishra, B. Systematic review on interaction studies of synthetic antidiabetic drugs and herbal therapies. J. Pharm. Res. 2017, 16, 86-94. [CrossRef]

11. EMA. European Medicines Agency. Committee on Herbal Medicinal Products (HMPC). Available online: https://www.ema. europa.eu/en/committees/committee-herbal-medicinal-products-hmpc (accessed on 30 April 2021).

12. Vinayagam, R.; Xu, B. Antidiabetic properties of dietary flavonoids: A cellular mechanism review. Nutr. Metab. 2015, 12, 1-20. [CrossRef]

13. Studzińska-Sroka, E.; Dudek-Makuch, M.; Chanaj-Kaczmarek, J.; Czepulis, N.; Korybalska, K.; Rutkowski, R.; Łuczak, J.; Grabowska, K.; Bylka, W.; Witowski, J. Anti-inflammatory Activity and Phytochemical Profile of Galinsoga Parviflora Cav. Molecules 2018, 23, 2133. [CrossRef]

14. Makowska-Wąs, J.; Galanty, A.; Gdula-Argasińska, J.; Tyszka-Czochara, M.; Szewczyk, A.; Nunes, R.; Carvalho, I.S.; Michalik, M.; Paśko, P. Identification of predominant phytochemical compounds and cytotoxic activity of wild olive leaves (Olea europaea L. ssp. sylvestris) harvested in south Portugal. Chem. Biodivers. 2017, 14, e1600331. [CrossRef] [PubMed]

15. Studzińska-Sroka, E.; Czapska, I.; Bylka, W. Biological Activity and Polyphenol Content in Selected Herbal Tea Blends Used in Diabetes. Acta Pol. Pharm. Res. 2019, 76, 1037-1042.

16. Dinis, T.C.P.; Madeira, V.M.C.; Almeida, L.M. Action of phenolic derivatives (acetaminophen, salicylate, and 5-aminosalicylate) as inhibitors of membrane lipid peroxidation and as peroxyl radical scavengers. Arch. Biochem. Biophys. 1994, 315, 161-169. [CrossRef]

17. Widodo, W.S.; Widowati, W.; Ginting, C.N.; Lister, I.; Armansyah, A.; Girsang, E. Comparison of antioxidant and anti-collagenase activity of genistein and epicatechin. Pharm. Sci. Res. 2019, 6, 6.

18. Hunyadi, A.; Martins, A.; Hsieh, T.J.; Seres, A.; Zupkó, I. Chlorogenic Acid and Rutin Play a Major Role in the In Vivo Anti-Diabetic Activity of Morus alba Leaf Extract on Type II Diabetic Rats. PLoS ONE 2012, 7, e50619. [CrossRef]

19. Frizzell, N.; Baynes, J.W. Chelation therapy for the management of diabetic complications: A hypothesis and a proposal for clinical laboratory assessment of metal ion homeostasis in plasma. Clin. Chem. Lab. Med. 2014, 52, 69-75. [CrossRef]

20. European Pharmacopoeia, 10th ed.; Council of Europe: Strasbourg, France, 2019; p. 1390, 1407-1409, 1551.

21. Brown, A.; Anderson, D.; Racicot, K.; Pilkenton, S.J.; Apostolidis, E. Evaluation of Phenolic Phytochemical Enriched Commercial Plant Extracts on the In Vitro Inhibition of $\alpha$-Glucosidase. Front. Nutr. 2017, 4, 56. [CrossRef] [PubMed]

22. Domínguez Avila, J.A.; Rodrigo García, J.; González Aguilar, G.A.; de la Rosa, L.A. The Antidiabetic Mechanisms of Polyphenols Related to Increased Glucagon-Like Peptide-1 (GLP1) and Insulin Signaling. Molecules 2017, 22, 903. [CrossRef]

23. Guo, H.; Xia, M.; Zou, T.; Ling, W.; Zhong, R.; Zhang, W. Cyanidin 3-glucoside attenuates obesity-associated insulin resistance and hepatic steatosis in high-fat diet-fed and db/db mice via the transcription factor FoxO1. J. Nutr. Biochem. 2012, 23, 349-360. [CrossRef] [PubMed]

24. Kawser Hossain, M.; Abdal Dayem, A.; Han, J.; Yin, Y.; Kim, K.; Kumar Saha, S.; Yang, G.-M.; Choi, H.Y.; Cho, S.-G. Molecular Mechanisms of the Anti-Obesity and Anti-Diabetic Properties of Flavonoids. Int. J. Mol. Sci. 2016, 17, 569. [CrossRef] [PubMed]

25. Kopustinskiene, D.M.; Jakstas, V.; Savickas, A.; Bernatoniene, J. Flavonoids as Anticancer Agents. Nutrients 2020, $12,457$. [CrossRef]

26. Peng, C.-H.; Lin, H.-T.; Chung, D.-J.; Huang, C.-N.; Wang, C.-J. Mulberry leaf extracts prevent obesity-induced NAFLD with regulating adipocytokines, inflammation and oxidative stress. J. Food Drug Anal. 2018, 26, 778-787. [CrossRef]

27. Yan, Y.; Zhou, X.; Guo, K.; Zhou, F.; Yang, H. Use of Chlorogenic Acid against Diabetes Mellitus and Its Complications. J. Immunol. Res. 2020, 2020, 9680508. [CrossRef]

28. Naveed, M.; Hejazi, V.; Abbas, M.; Kamboh, A.A.; Khan, G.J.; Shumzaid, M.; Ahmad, F.; Babazadeh, D.; FangFang, X.; ModarresiGhazani, F.; et al. Chlorogenic acid (CGA): A pharmacological review and call for further research. Biomed. Pharmacother. 2018, 97, 67-74. [CrossRef]

29. Zuñiga, L.Y.; Aceves-de la Mora, M.C.A.; González-Ortiz, M.; Ramos-Núñez, J.L.; Martínez-Abundis, E. Effect of Chlorogenic Acid Administration on Glycemic Control, Insulin Secretion, and Insulin Sensitivity in Patients with Impaired Glucose Tolerance. J. Med. Food 2018, 21, 469-473. [CrossRef]

30. Adefegha, S.A.; Oboh, G.; Ejakpovi, I.I.; Oyeleye, S.I. Antioxidant and antidiabetic effects of gallic and protocatechuic acids: A structure-function perspective. Comp. Clin. Pathol. 2015, 24, 1579-1585. [CrossRef]

31. Patel, S.S.; Goyal, R.K. Cardioprotective effects of gallic acid in diabetes-induced myocardial dysfunction in rats. Pharmacogn. Res. 2011, 3, 239-245. [CrossRef]

32. Polumackanycz, M.; Wesolowski, M.; Viapiana, A. Morus alba L. and Morus nigra L. Leaves as a Promising Food Source of Phenolic Compounds with Antioxidant Activity. Plant Foods Hum. Nutr. 2021, 1-8. [CrossRef] [PubMed]

33. Miyake, K.; Arima, H.; Hirayama, F.; Yamamoto, M.; Horikawa, T.; Sumiyoshi, H.; Noda, S.; Uekama, K. Improvement of solubility and oral bioavailability of rutin by complexation with 2-hydroxypropyl-beta-cyclodextrin. Pharm. Dev. Technol. 2000, 5, 399-407. [CrossRef]

34. Kim, G.-N.; Jang, H.-D. Flavonol content in the water extract of the mulberry (Morus alba L.) leaf and their antioxidant capacities. J. Food Sci. 2011, 76, C869-C873. [CrossRef] [PubMed]

35. Hwang, S.H.; Li, H.M.; Lim, S.S.; Wang, Z.; Hong, J.-S.; Huang, B. Evaluation of a standardized extract from morus alba against $\alpha$-glucosidase inhibitory effect and postprandial antihyperglycemic in patients with impaired glucose tolerance: A randomized double-blind clinical trial. Evid. Based Complementary Altern. Med. 2016, 2016, 8983232. [CrossRef] 
36. Dabur, R.; Sharma, B.; Mittal, A. Mechanistic approach of anti-diabetic compounds identified from natural sources. Chem. Biol. Lett. 2018, 5, 63-99.

37. Zheng, Y.; Yang, W.; Sun, W.; Chen, S.; Liu, D.; Kong, X.; Tian, J.; Ye, X. Inhibition of porcine pancreatic $\alpha$-amylase activity by chlorogenic acid. J. Funct. Foods 2020, 64, 103587. [CrossRef]

38. Dubey, S.; Ganeshpurkar, A.; Ganeshpurkar, A.; Bansal, D.; Dubey, N. Glycolytic enzyme inhibitory and antiglycation potential of rutin. Future J. Pharm. Sci. 2017, 3, 158-162. [CrossRef]

39. Ranilla, L.G.; Kwon, Y.-I.; Apostolidis, E.; Shetty, K. Phenolic compounds, antioxidant activity and in vitro inhibitory potential against key enzymes relevant for hyperglycemia and hypertension of commonly used medicinal plants, herbs and spices in Latin America. Bioresour. Technol. 2010, 101, 4676-4689. [CrossRef] [PubMed]

40. Adisakwattana, S.; Lerdsuwankij, O.; Poputtachai, U.; Minipun, A.; Suparpprom, C. Inhibitory activity of cinnamon bark species and their combination effect with acarbose against intestinal $\alpha$-glucosidase and pancreatic $\alpha$-amylase. Plant Foods Hum. Nutr. 2011, 66, 143-148. [CrossRef]

41. Adisakwattana, S. Cinnamic Acid and Its Derivatives: Mechanisms for Prevention and Management of Diabetes and Its Complications. Nutrients 2017, 9, 163. [CrossRef]

42. Lin, G.-M.; Chen, Y.-H.; Yen, P.-L.; Chang, S.-T. Antihyperglycemic and antioxidant activities of twig extract from Cinnamomum osmophloeum. J. Tradit. Complementary Med. 2016, 6, 281-288. [CrossRef]

43. Tao, Y.; Zhang, Y.; Cheng, Y.; Wang, Y. Rapid screening and identification of $\alpha$-glucosidase inhibitors from mulberry leaves using enzyme-immobilized magnetic beads coupled with HPLC/MS and NMR. Biomed. Chromatogr. 2013, 27, 148-155. [CrossRef] [PubMed]

44. Sui, X.; Zhang, Y.; Zhou, W. In vitro and in silico studies of the inhibition activity of anthocyanins against porcine pancreatic $\alpha$-amylase. J. Funct. Foods 2016, 21, 50-57. [CrossRef]

45. Barik, S.K.; Russell, W.R.; Moar, K.M.; Cruickshank, M.; Scobbie, L.; Duncan, G.; Hoggard, N. The anthocyanins in black currants regulate postprandial hyperglycaemia primarily by inhibiting $\alpha$-glucosidase while other phenolics modulate salivary $\alpha$-amylase, glucose uptake and sugar transporters. J. Nutr. Biochem. 2020, 78, 108325. [CrossRef]

46. Boath, A.S.; Stewart, D.; McDougall, G.J. Berry components inhibit $\alpha$-glucosidase in vitro: Synergies between acarbose and polyphenols from black currant and rowanberry. Food Chem. 2012, 135, 929-936. [CrossRef] [PubMed]

47. Chokki, M.; Cudălbeanu, M.; Zongo, C.; Dah-Nouvlessounon, D.; Ghinea, I.O.; Furdui, B.; Raclea, R.; Savadogo, A.; Baba-Moussa, L.; Avamescu, S.M. Exploring antioxidant and enzymes (A-amylase and B-Glucosidase) inhibitory activity of Morinda lucida and Momordica charantia leaves from Benin. Foods 2020, 9, 434. [CrossRef]

48. Castro-Acosta, M.L.; Smith, L.; Miller, R.J.; McCarthy, D.I.; Farrimond, J.A.; Hall, W.L. Drinks containing anthocyanin-rich blackcurrant extract decrease postprandial blood glucose, insulin and incretin concentrations. J. Nutr. Biochem. 2016, 38, 154-161. [CrossRef]

49. Tsui, P.-F.; Lin, C.-S.; Ho, L.-J.; Lai, J.-H. Spices and atherosclerosis. Nutrients 2018, 10, 1724. [CrossRef]

50. Jin, Q.; Yang, J.; Ma, L.; Wen, D.; Chen, F.; Li, J. Identification of polyphenols in mulberry (genus Morus) cultivars by liquid chromatography with time-of-flight mass spectrometer. J. Food Compos. Anal. 2017, 63, 55-64. [CrossRef]

51. Ouyang, P.; Gottlieb, S.H.; Culotta, V.L.; Navas-Acien, A. EDTA chelation therapy to reduce cardiovascular events in persons with diabetes. Curr. Cardiol. Rep. 2015, 17, 1-9. [CrossRef]

52. Lakey-Beitia, J.; Burillo, A.M.; La Penna, G.; Hegde, M.L.; Rao, K.S. Polyphenols as Potential Metal Chelation Compounds Against Alzheimer's Disease. J. Alzheimer's Dis. 2021, 82, S335-S357. [CrossRef] [PubMed]

53. Santana-Gálvez, J.; Cisneros-Zevallos, L.; Jacobo-Velázquez, D.A. Chlorogenic Acid: Recent Advances on Its Dual Role as a Food Additive and a Nutraceutical against Metabolic Syndrome. Molecules 2017, 22, 358. [CrossRef] [PubMed]

54. Sharma, U.K.; Sharma, A.K.; Pandey, A.K. Medicinal attributes of major phenylpropanoids present in cinnamon. BMC Complementary Altern. Med. 2016, 16, 156. [CrossRef] [PubMed]

55. Łabuda, H.; Buczkowska, H.; Papliński, R.; Najda, A. Secondary metabolites of Phaseoli pericarpium. Acta Sci. Pol. Hortorum Cultus 2017, 16, 187-200. [CrossRef]

56. Druzynska, B.; Klepacka, M. Wlasciwosci przeciwutleniajace preparatow polifenoli otrzymanych z okrywy nasiennej fasoli czarnej, rozowej i bialej [Phaseolus]. Żywność Nauka Technol. Jakość 2004, 11, 69-78.

57. Adhikari, B.M.; Bajracharya, A.; Shrestha, A.K. Comparison of nutritional properties of Stinging nettle (Urtica dioica) flour with wheat and barley flours. Food Sci. Nutr. 2016, 4, 119-124. [CrossRef]

58. Otles, S.; Yalcin, B. Phenolic compounds analysis of root, stalk, and leaves of nettle. Sci. World J. 2012, 2012, 564367. [CrossRef]

59. Carrasco-Castilla, J.; Hernández-Álvarez, A.J.; Jiménez-Martínez, C.; Jacinto-Hernández, C.; Alaiz, M.; Girón-Calle, J.; Vioque, J.; Dávila-Ortiz, G. Antioxidant and metal chelating activities of peptide fractions from phaseolin and bean protein hydrolysates. Food Chem. 2012, 135, 1789-1795. [CrossRef]

60. Gülçin, I.; Küfrevioglu, O.I.; Oktay, M.; Büyükokuroglu, M.E. Antioxidant, antimicrobial, antiulcer and analgesic activities of nettle (Urtica dioica L.). J. Ethnopharmacol. 2004, 90, 205-215. [CrossRef] [PubMed]

61. Balci Yuce, H.; Karatas, Ö.; Tulu, F.; Altan, A.; Gevrek, F. Effect of diabetes on collagen metabolism and hypoxia in human gingival tissue: A stereological, histopathological, and immunohistochemical study. Biotech. Histochem. 2019, 94, 65-73. [CrossRef]

62. Pradeepkumar Singh, L.; Vivek Sharma, A.; Swarnakar, S. Upregulation of collagenase-1 and-3 in indomethacin-induced gastric ulcer in diabetic rats: Role of melatonin. J. Pineal Res. 2011, 51, 61-74. [CrossRef] [PubMed] 
63. Thrailkill, K.M.; Bunn, R.C.; Moreau, C.S.; Cockrell, G.E.; Simpson, P.M.; Coleman, H.N.; Frindik, J.P.; Kemp, S.F.; Fowlkes, J.L. Matrix metalloproteinase-2 dysregulation in type 1 diabetes. Diabetes Care 2007, 30, 2321-2326. [CrossRef]

64. Drankowska, J.; Kos, M.; Kościuk, A.; Marzęda, P.; Boguszewska-Czubara, A.; Tylus, M.; Święch-Zubilewicz, A. MMP targeting in the battle for vision: Recent developments and future prospects in the treatment of diabetic retinopathy. Life Sci. 2019, 229, 149-156. [CrossRef]

65. Kozakova, M.; Morizzo, C.; Goncalves, I.; Natali, A.; Nilsson, J.; Palombo, C. Cardiovascular organ damage in type 2 diabetes mellitus: The role of lipids and inflammation. Cardiovasc. Diabetol. 2019, 18, 1-11. [CrossRef]

66. Anuar, N.N.M.; Zulkafali, N.I.N.; Ugusman, A. Modulation of Matrix Metalloproteinases by Plant-derived Products. Curr. Cancer Drug Targets 2021, 21, 91-106. [CrossRef] [PubMed]

67. Shukri, S.M.; Pardi, F.; Sidik, N.J. In Vitro anti-collagenase activity and total phenolic content of five selected herbs: A review. Sci. Lett. 2021, 15, 117-127. [CrossRef]

68. Thring, T.S.A.; Hili, P.; Naughton, D.P. Anti-collagenase, anti-elastase and anti-oxidant activities of extracts from 21 plants. BMC Complementary Altern. Med. 2009, 9, 27. [CrossRef]

69. Wittenauer, J.; Mäckle, S.; Sußmann, D.; Schweiggert-Weisz, U.; Carle, R. Inhibitory effects of polyphenols from grape pomace extract on collagenase and elastase activity. Fitoterapia 2015, 101, 179-187. [CrossRef] [PubMed]

70. Salam, M.A.; Al-Zhrani, G.; Kosa, S.A. Simultaneous removal of copper(II), lead(II), zinc(II) and cadmium(II) from aqueous solutions by multi-walled carbon nanotubes. C. R. Chim. 2012, 15, 398-408. [CrossRef]

71. Choi, E.-Y.; Kim, E.-H.; Lee, J.-B.; Do, E.-J.; Kim, S.-J.; Kim, S.-H.; Park, J.-Y.; Lee, J.-T. Mechanisms for anti-wrinkle activities from fractions of Black Chokeberries. J. Life Sci. 2016, 26, 34-41. [CrossRef] 